\title{
Development of Nematophagous Fungi on Dead Adults of Aedes aegypti (Diptera: Culicidae) and Molt Inhibition Experimental
}

\author{
Fabio Ribeiro Braga ${ }^{1 \text { A }}$, Filippe Elias Freitas Soares ${ }^{2}$, Gracilene Maria Almeida Muniz \\ Braga $^{3}$, Juliana Milani Araujo ${ }^{1}$, Lorendane Millena de Carvalho ${ }^{1}$, Emy Hiura, \\ Anderson Rocha Aguiar, Carolina Magri Ferraz, Alessandra Teixeira de Paula ${ }^{1}$, \\ Rosana Teixeira Lelis ${ }^{4}$, Rosane Teixeira Lelis ${ }^{1}$, Marilvia Dansa de Alencar ${ }^{4}$, \\ Rafaela Lorenzoni ${ }^{\mathrm{A}}$ and Jackson Victor Araújo ${ }^{1 *}$ \\ ${ }^{1}$ Departamento de Veterinária, Universidade Federal de Viçosa, Viçosa, MG, Brazil \\ ${ }^{A}$ Universidade Vila Velha, Vila Velha ES \\ ${ }^{2}$ Departamento de Bioquímica e Biologia Molecular, Universidade Federal de Viçosa, \\ Viçosa, MG, Brazil \\ ${ }^{3}$ Escola Superior de Ciências da Santa Casa de Misericordia de Vitoria - EMESCAM \\ ${ }^{4}$ Universidade Estadual do Norte Fluminense, Campos dos Goytacazes, RJ, Brazil \\ *Corresponding author
}

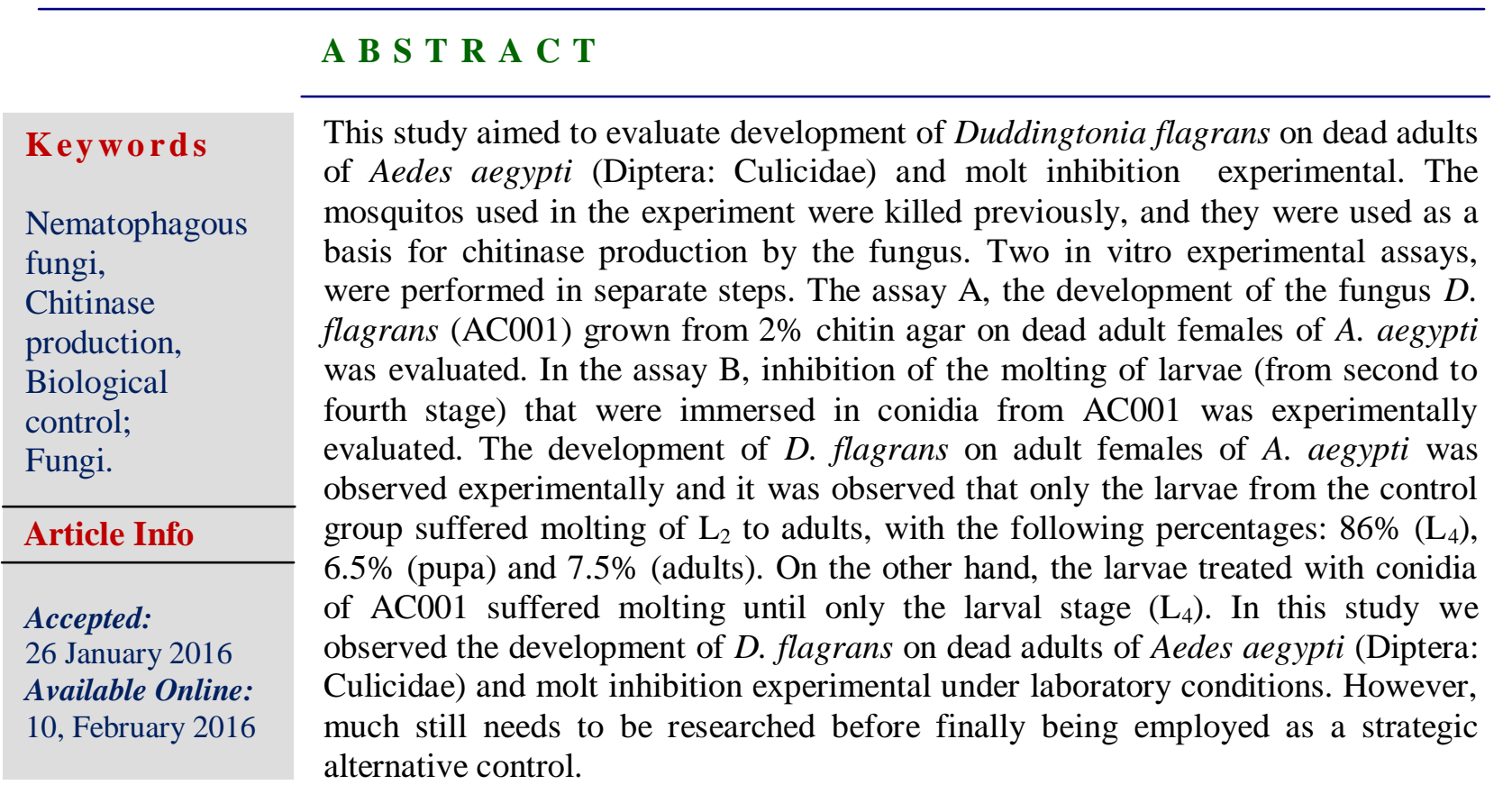

\section{Introduction}

Aedes aegypti (Diptera: Culicidae) is the principal urban vector of dengue,
Chikungunya and Zika (Gibbons \& Vaughan, 2002, Vasconcelos, 2015). The 
absence of an effective vaccine against dengue, chikungunya and zika virus makes essential the realization of actions to control populations of the vector of this disease. Control of $A$. aegypti has been conducted over the years, by means of chemical control, based on the use of organophosphate insecticides (Furtado et al., 2005) and insect growth regulators (Lucia et al., 2009; Salokhe et al., 2012; Silva \& Mendes, 2007). However, there is a growing concern about the use of chemicals insecticides in relation to selection of Aedes spp. populations resistant to the same (Dusfour et al., 2011; Lima et al., 2011; Prophiro et al., 2011; Tikar, Kumar, Prasad \& Prakash, 2009). Several studies have been performed encompassing the biological control with entomopathogenic fungi in an attempt to develop alternative methods to chemical control of $A$. aegypti (Kay \& Vu, 2005; Leles et al., 2010; Leles \& D`Alesandro, 2011; Luz et al., 2007, 2008; Scholte, Takke \& Knols, 2007; Silva et al., 2004). However, the use of other groups of fungi, such as nematophagous fungi and their extracellular enzymes on arthropod vectors of diseases have been successfully tested (Bogum et al., 2005; Braga \& Araújo, 2014, Azevedo et al., 2015).

Braga et al., (2013) and Azevedo et al., (2015) reported the development and the enzimatic activity of nematophagous fungi with entomopathogenic activity against ticks species, vector of diseases, starting from the principle that the exoskeleton of arthropods is composed of chitin, one polysaccharide that is recognized by the lectins from the most of nematophagous fungi.

Arthropods are good sources of chitin under laboratory conditions. In this sense, the activity of $D$. flagrans could be tested on other arthropods. However, this study aimed to evaluate the development of $D$. flagrans on dead adults of $A$. aegypti that were used as a basis for chitinase production by the fungus.

In Brazil the introduction and rapid dispersion process of two new arboviruses for the Americas, the Chikungunya virus, probably introduced in 2014 and the Zika virus, possibly introduced in the period during the World Cup held in 2014, emphasizes the need in improving the control in areas infested with $A$. aegypti. Therefore, it is increasing the enormous challenge of epidemiological surveillance in early detection of the new areas with transmission to minimize the impact of these diseases in the population (Vasconcelos, 2015). Thus, new control strategies may come to add other existing.

This study aimed to evaluate the development of Duddingtonia flagrans on dead adults of Aedes aegypti (Diptera: Culicidae) and molt inhibition experimental under laboratory conditions.

\section{Materials and Methods}

\section{Fungus}

An isolate of the nematophagous fungus $D$. flagrans (AC001) was used. This isolate is kept in test tubes at $4{ }^{\circ} \mathrm{C}$ containing $2 \%$ corn-meal-agar (2\% CMA) and in the dark for 10 days. This isolated is derived from soil Viçosa, Minas Gerais, Brazil and comes from mycology collection of the Laboratory of Parasitology, Department of Veterinary Medicine of the Federal University of Viçosa, Minas Gerais, Brazil .It have continually been transferred to various media and among them Agar-chitin (2\% CA) Braga et al., (2013).

\section{Conidia Production}

To obtain conidia, $10 \mathrm{ml}$ of water containing $0.1 \%$ Tween 80 was added to the plates 
containing the fungus grown on $2 \%$ chitinagar. The obtained suspension was stirred with glass beads in a vortex apparatus and then filtered on absorbent cotton, following the methodology used by Sousa et al., (2006). The quantification of conidia was performed with a Neubauer chamber.

\section{Obtaining Larvae and Adults of Aedes aegypti}

The mosquitos used in the experiment were killed previously, and they were used as a basis for chitinase production by the fungus. Aedes aegypti from Rockefeller strain, obtained from a colony present at the Laboratory of Chemistry and Function of Proteins and Peptides (LQFPP) State University of North Fluminense (UENF) were kept in cages containing aqueous solution of $10 \%$ sucrose. Eggs were collected and kept in a container with water for two days. The larvae were feed with commercial food for mouse manually ground (approximately $5 \mathrm{~g}$ per 100 larvae/vial). From to 3-5 days after egg hatching and emergence of the larvae, pupae were removed with the aid of a Pasteur pipette reversed. The larvae were then transferred to a plate that was kept inside a cage, until emergence of adults. In the adult phase, mosquitoes were fed with sucrose solution $(10 \%)$ for maintenance and females were fed with rabbit blood for egg laying and/or experimental procedures (Lelis, 2012).

\section{Assays}

Two in vitro assays, named $\mathrm{A}$ and $\mathrm{B}$, were performed in separate steps. In the assay A, the development of the fungus $D$. flagrans (AC001) grown from 2\% chitin agar on dead adult females of $A$. aegypti was evaluated under laboratory conditions. In the assay $\mathrm{B}$, inhibition of the molting of larvae (from second to fourth stage) that were immersed in conidia from $D$. flagrans (AC001) was experimentally evaluated.

\section{Assay A}

\section{Development of the Fungus on Dead Adult Females of A. aegypti}

In this assay the methodology described by Braga et al., (2013) has been followed, where dead adult females of $A$. aegypti were washed in distilled water, dry and placed on sterilized filter paper to remove excess of water. They were then separated and immersed for 5 seconds in fungal suspension with $10^{6}$ conidia/ml of the fungus $D$. flagrans grown in $2 \% \mathrm{CA}$ and placed in Petri dishes (6 cm diameter) and incubated in BOD (Biological Oxygen Demand) at 25 $\pm 1^{\circ} \mathrm{C}$ and $80 \pm 10 \%$ relative humidity, in the dark. Two groups were formed, one group treated with the dilution described above and one control group. Each Petri dish of treated and control groups contained 5 specimens, totaling 30 individuals for each treatment, with 6 repetitions. In the control group, females were immersed in distilled water for 5 seconds and incubated in BOD at $25 \pm 1{ }^{\circ} \mathrm{C}$ and $80 \pm 10 \%$ relative humidity in the dark. The colonization of the fungus on the females of $A$. aegypti was monitored daily for 7 days (Lopes et al., 2008). After colonization, the arthropods were disinfected in accordance with the methodology of Alves (1998). Colonization was assessed by visualization of microstructures characteristics (conidia and/or chlamydospores), according to the criteria of Duddington (1955) and Van Orschot (1985).

\section{Assay B}

The percentage inhibition of molting of larvae between stages $\left(\mathrm{L}_{2}\right)$ to pupa was 
experimentally evaluated. The concentration of $10^{6}$ conidia ml was used. Two groups, a control group and a treated group, with six repetions per group, were formed using plastic cups $3.5 \times 4.2 \mathrm{~cm}$ that were covered with a transparent mesh. The treated group was formed by adding twenty second stage larvae $\left(\mathrm{L}_{2}\right)$ of $A$. aegypti and $18 \mathrm{ml}$ of autoclaved distilled water, and then $2 \mathrm{ml}$ of the spore suspension. The control group contained only $20 \mathrm{ml}$ of autoclaved distilled water and $20 \mathrm{~L}_{2}$. The larvae were incubated in a environmental chamber at $25^{\circ} \mathrm{C}$ and manually fed every two days with grinded ration for mouse. Every day, the groups were observed for changes in the larval to pupal stage (Sousa, Santos, Elias \& Luz, 2006).

\section{Results and Discussion}

In the assay A, the colonization of conidia of the fungus $D$. flagrans (AC001) produced from $2 \% \mathrm{CA}$ was evidenced on dead adult females of $A$. aegypti. The proof of this colonization could be observed after the visualization of growth of the conidia (AC001) (Fig 1. A-I). Then, the fungus was reisolated in Petri dishes containing medium $2 \% \mathrm{WA}$ and the presence of simple adhesive hyphae and conidia with $25-50 \mu \mathrm{m}$ in length and $10-15 \mu \mathrm{m}$ in width was proven, as observed by Braga et al., (2013) (Fig. 1. I).

In the assay $\mathrm{B}$, it was observed that only the larvae from the control group suffered molting of $\mathrm{L}_{2}$ to adults, with the following percentages: $86 \%\left(\mathrm{~L}_{4}\right), 6.5 \%$ (pupa) and $7.5 \%$ (adults), in the control group. On the other hand, the larvae treated with conidia of D. flagrans suffered molting until only the larval stage $\left(\mathrm{L}_{4}\right)$, at the end of seven days (Fig. 2A).

Arthropods are good sources of chitin under laboratory conditions and in the assay A, the development of Duddingtonia flagrans on dead adults of Aedes aegypti (Fig. IA) by the fungus grown in medium $2 \% \mathrm{CA}$ was demonstrated. This information is particularly important in the biological point of view, since there is the abundant presence of chitin. However, the authors also point out that dead adults insects were used, in order to observe a possible colonization from the supplementation of the fungus in a rich chitin-based medium and through the end of the experiment were able to observe the internal colonization of insects through visualization of chlamydospores (Fig .1-I). However, as previously mentioned, the particularities of arthropods classes should be taken into account. Nematophagous fungi are known to "eaters of helminths" and have proven their worth over the years (Barron, 1977; Gronvold et al., 1996; Larsen, 1999). However, some genera of these fungi have entomopathogenic potential as, for example, the genus Paecilomyces. In this regard, Fiedler \& Sosnwska (2007) have demonstrated the pathogenicity of the nematophagous fungus Purpureocillium lilacinum (formerly Paecilomyces lilacinus) on a number of potentially harmful arthropods in agriculture. In the work of Braga et al., (2013) was evidenced for the first time the production of a chitinase by the nematophagous fungus $D$. flagrans (AC001), which plays an important role in the fungus $\mathrm{x}$ arthropods infection process.

In the assay B, experimentally it was observed that the conidia of D. flagrans (AC001) obtained from growth in medium $2 \%$ CA somehow inhibited the change in larval stages to adults. These results are in agreement with the work of Braga et al., (2013) who proposed that conidia from the medium 2\% CA were essential for the interaction and subsequent destruction of engorged females of $A$. cajenense, however, the authors call attention to certain points: (a) in that study, conidia were produced from agar with Amblyomma cajenense 
chitin; (b) There are no protocols for the use of chitinase derived from nematophagous fungi on arthropods, with only one report cited earlier; (c) the authors suggest that the interaction of the fungus $D$. flagrans with the arthropod was possible due to the action of a chitinase produced by this fungus, enzyme which has had its production induced by the growth of the fungus in culture medium rich in chitin ( $2 \% \mathrm{CA})$.

Figure.1 A-H. Development of Duddingtonia Flagrans on Dead Adults of Aedes aegypti (Diptera: Culicidae). I. Presence of D. Flagrans Chlamydospores on the Colonized Insect

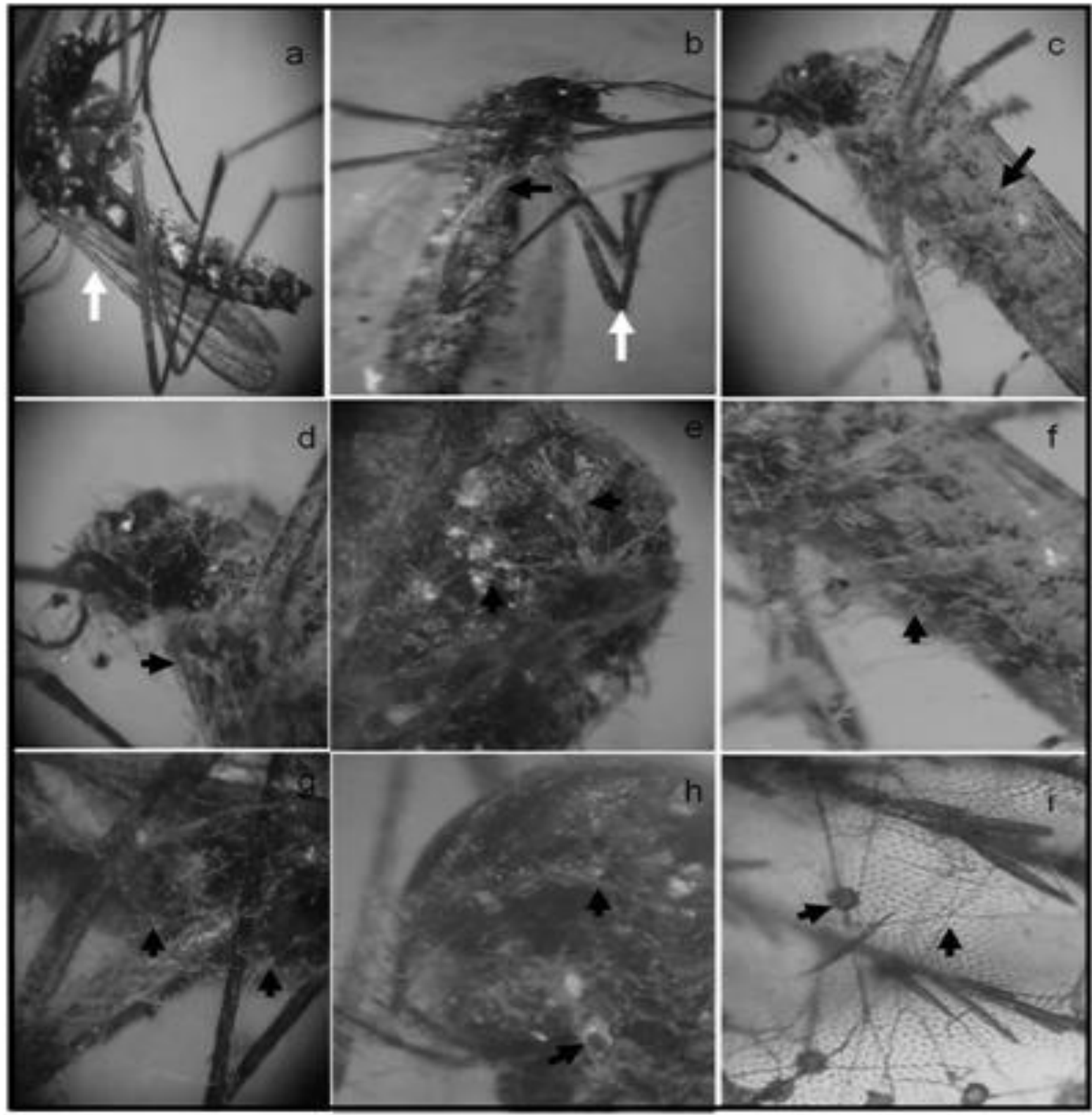


Figure.2A-C- A Larvae (L4); B (pupa) and C (adults) of Aedes aegypti in the Control Group without Treatment with Duddingtonia Flagrans Conidia, after Seven Days

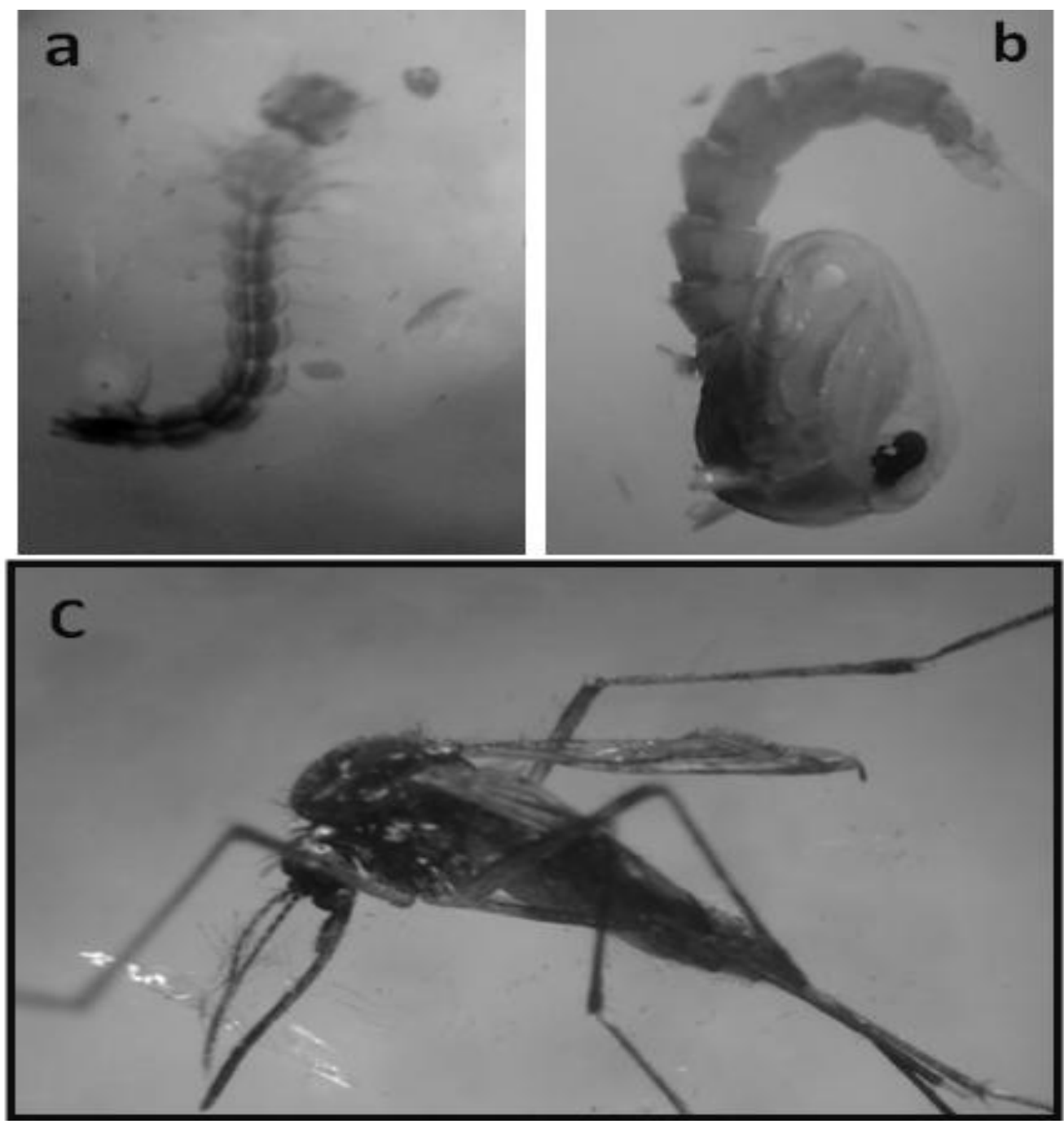

Another important point that deserves to be discussed is the concentration of conidia used in the in vitro control of A. aegypti. Most papers mention that concentrations may vary $10^{6}-10^{8}$ conidia $/ \mathrm{mL}$ (Leles et al., 2011; Santos et al., 2009; Scholte et al., 2007). However, these studies focus on the use of entomopathogenic fungi. In this paper, the authors suggest that the concentration of $10^{6}$ conidia/mL was enough for the inhibition of larval stage and subsequent colonization of the adult insects and thus, the authors call attention to the first report of the interaction of spores from a nematophagous fungus (AC001) on larvae of $A$. aegypti, which in the future may prove to be an additional tool of research.

In this study we observed the development of D. flagrans on dead adults of Aedes aegypti (Diptera: Culicidae) and molt inhibition experimental under laboratory conditions. The authors mention that the mosquitoes used in the experiment were killed previously, serving only as a basis for chitinase production by the fungus. 
However, much still needs to be researched before finally being employed as a strategic alternative control.

\section{Acknowledgment}

The authors also would like to thank $\mathrm{CNPq}$, Capes, Fapes and Fapemig for financial support and grant concession.

\section{References}

Alves SB. Controle Microbiano de Insetos. Piracicaba FEALQ. 1998; 1163 pp.

Araujo, J.M., Braga, F.R., Araújo, J.V., Soares, F.E.F., Genier, H.LA., 2010. Biological control of Taenia saginata eggs. Helminthology. 47:189-192.

Araújo, J.V., Santos, M.A., Ferraz, S., 1995. Efeito ovicida de fungos nematófagos sobre ovos embrionados de Toxocara canis. Arquivo Brasileiro de Medicina Veterinária e Zootecnia. 47:37-42.

Azevedo, T. P., Hiura, E., Andrade, M.C., Lopes, A.C.G., Aguiar, A.R., Lenz, D., Leite, F.L.G., Araújo, J.V., Braga F.R., 2015. In Vitro activity of the Nematophagous Fungi Pochonia chlamydosporia on Rhipicephalus (Boophilus) microplus Ticks. 12: 727-734.

Barron GL., 1977. The nematode-destroying fungi. Topics in Mycology No. 1. Canadian Biological Publications Ltd., Guelph, Ontario, Canada.

Braga, F.R., Araújo, J.V., 2014. Nematophagous fungi for biological control of gastrointestinal nematodes in domestic animals. Applied Microbiology and Biotechnology. 98:71-82.

Braga, F.R., Araújo, J.V., Araujo, J.M., Carvalho, R.O., Silva, A.R., Campos, A.K., Tavela, A.O., 2008.
Ovicidal activity of Paecilomyces lilacinus on Moniezia sp. eggs. Journal of Helminthology. 10:1-3.

Braga, F.R., Araújo, J.V., Soares, F.E.F., Araujo, J.M., Tavela, A.O., Mello, I.N.K., Carvalho, LM.,. Paula, A.T., Lelis, R.T., 2013. Queiroz JH. Interaction of the nematophagous fungus Duddingtonia flagrans on Amblyomma cajannense engorged females and enzymatic characterization of its chitinase. Biocontrol Science and Technology. 25:584-594.

Bogum, M.I., Czygier, M.,. Kddra, E., Samborski, J., 2005. In vitro assessment of the influence of nutrition and temperature on growing rates of five Duddingtonia flagrans isolates, their insecticidal properties and ability to impair Heligmosomoides polygyrus motility. Experimental Parasitology. 109:115-123.

Dick, G.W.A., Kitchen, S.F., Haddow, A.J., 1952. Zika virus I. Isolation and serological specificity. Trans Roy Soc Trop Med Hyg. 46:509-20.

Dusfour, I., Tahlmensy, V., Gaborit, P., Issaly, J., Carinci, R., Girod, R., 2011. Multiple insecticide resistance in Aedes aegypti (Diptera: Culicidae) populations compromises the effectiveness of dengue vector control in French Guiana. Memorias do Instituto Oswaldo Cruz. 106:346352.

Duddington, C.L., 2015. Notes on the technique of handling predaceous fungi. Transactions of the British Mycological Society. 38:97-103.

Fiedler, Z., Sosnowska, D, 2007. Nematophagous fungus Paecilomyces lilacinus pests. Biological Control. 52:547-558. 
Furtado, R.F., Lima, M.G.A., Neto, M.A., Bezerram J.N.S., Silva, M.G.V, 2005. Atividade larvicida de óleos essenciais contra Aedes aegypti L. (Diptera: Culicidae). Neotropical Entomology. 34:1519-1566.

Gibbons, R.V., Vaughan, D.W., 2002. Dengue: an escalating problem. BMJ. 324:1563-1566.

Gronvold, J., Henriksen, S.A., Larsen, M., Nansen, P., Wolstrup, J., 1996. Biological control: Aspects of biological control- with special reference to arthropods, protozoans and helminthes of domesticated livestock. Veterinary Parasitology. 64:47-64.

Kay, B., Vu, S.N., 2005. New strategy against Aedes aegypti in Vietnam. Lancet. 365:613-617.

Leles, R.N., Souza, N.A., Rocha, N.L.F., Santos, A.H., Silva, H.H., Luz, C., 2010. Pathogenicity of some hiprocrealen fungi to adult Aedes aegypti (Diptera: Culicidae). Parasitology Research. 107:12711274.

Leles, R.N., D’Alessandro, W.B., Luz, C,. 2011. Effects of Metarhizium anisopliae conidia mixed with soil against the eggs of Aedes aegypti. Parasitology Research.110:15791582.

Lelis, RT., 2012. Efeitos de Extratos de Plantas da Mata Atlântica em Aedes aegypti. Monografia para obtenção do título de Bacharel em Ciências Biológicas. Campos dos Goytacazes. 2012.

Lima, E.P., Paiva, M.H.S., Araújo, A.P., Silva, E.V.G., Silva, U.M., Oliveira, L.N., Santana, A.E.G., Barbosa, C.N., Neto, C.C.P., Goulart, M.O.F., Wilding, C.S., Ayres C.F.J., Santos, M.A.V.M., 2011. Insecticide resistance in Aedes aegypti populations from Ceara, Brazil. Parasite amd Vectors. 4:1-12.

Lopes, R.S., Portela, A.P.A.S., Svedese, V.M., Albuquerque, A.C., LunaAlves, L.E.A., 2008. Aspectos morfológicos de Paecilomyces farinosus sobre infecção em Coptotermes gestroi GESTROI. (Wasmann) (ISOPTERA: Rhinotermitidae). Biológico. 70:2933.

Luz, C., Tai, M.H.H., Santos, A.H., Rocha, L.N.F., Albernaz, D.A.S., Silvam H.H.G., 2007. Ovicidal activity of entomopathogenic hyphomycetes on Aedes aegypti (Dipetera: Culicidae) under laboratory conditions. Journal of Medical Entomology. 44:799-804.

Luz, C., Tai, M.H.H., Santos, A.H, Silva, H.H.G, 2008. Impact of moisture on survival of Aedes aegypti eggs and ovicidal activity of Metarhizium anisopliae under laboratory conditions. Memorias do Instituto Oswaldo cruz. 103:214-215.

Lucia, A., Harburguer, L., Licastro, S., Zerba, E., Masuh, H., 2009. Efficacy of a new combined larvicidaladulticidal ultralow volume formulation against Aedes aegypti (Diptera: Culicidae), vector of dengue. Parasitology Research. 104:1101-1107.

Prophiro, J.S., Silva, O.S., Luna, J.E., Piccoli, C.F., Kanism L.A., Silva, M.A., 2011. Aedes aegypti and Aedes albopictus (Diptera: Culicidae): coexistence and susceptibility to temephos, in municipalities with occurrence of dengue and differentiated characteristics of urbanization. Revista da Sociedade Brasileira de Medicina Tropical. 44:300-305.

Salokhe, S.G., Deshpande, S.G., Mukherjee, S.N., 2012. Evaluation of the insect 
growth regulator Lufenuron (Match $\left.{ }^{\circledR}\right)$ for control of Aedes aegypti by simulated field trials. Parasitology Research. 111:13251329.

Santos, A.H., Tai, M.H.H., Rocha, L.F.N., Silva, H.H.G., Luz, C., 2009 Dependence of Metharizium anisopliae on high humidity for ovicidal activity. Biological Control. 50:37-42.

Silva, R.O., Silva, H.H.G., Luz, C, 2004. Effect of Metarhizium anisopliae isolated from soil samples of the central Brazilian cerrado against Aedes aegypti larvae under laboratory conditions. Revista de Patologia Tropical. 33:207-216.

Silva, J.J., Mendes, J., 2007. Susceptibility of Aedes aegypti (L) to the insect growth regulators diflubenzuron and methoprene in Uberlândia, State of Minas Gerais. Revista da Sociedade Brasileira de Medicina Tropical. 40:612-616.

Sousa, P.O., Santos, A.H., Elias, C.N., Luz, C. 2006. Atividade larvicida de Tolypocladium cylindrosporum e Metarhizium spp. em mosquitos. Congresso De Pesquisa, Ensino E Extensão Da Ufg - Conpeex, 3., 2006, Goiânia. Anais eletrônicos do XIV Seminário de Iniciação Cientifica [CD-ROM], Goiânia: UFG, 2006. n.p.
Scott, T.W., Takken, W., 2012. Feeding strategies of anthropophilic mosquitoes result in increased risk of pathogen transmission. Trends Parasitogy. 28:114-121.

Scholte, E.J., Takke, W., Knols, B.G.J., 2007. Infection of adult Aedes aegypti and Ae. albopictus mosquitoes with the entomopathogenic fungus Metarhizium anisopliae. Acta Tropica. 102:151-158.

Tikar, S.N., Kumar, A., Prasad, G.B., Prakash, S. 2009. Temephos-induced resistance in Aedes aegypti and its cross-resistance studies to certain insecticides from India. 2009. Parasitology Research. 105:57-63.

Van Orschot CAN. 1985. Taxonomy of the Dactylaria complex. A review of Arthrobotrys and allied genera. Studies in Mycology. 26:61-95.

Vasconcelos, P.F.C. 2015. Zika virus disease: is it a new emerging problem in the Americas? Revista Pan-Amaz Saúde. 6:9-10

WHO: Dengue - guidelines for diagnosis, treatment, prevention and control. WHO, Geneva, WHO/ HTM/ NTD/ DEN/2009.1, 2009; pp.1-147.

WHO: Dengue and severe dengue. Geneva. 2012; Fact sheet no. 117.

\section{How to cite this article:}

Fabio Ribeiro Braga, Filippe Elias Freitas Soares, Gracilene Maria Almeida Muniz Braga, Juliana Milani Araujo, Lorendane Millena de Carvalho, Emy Hiura, Anderson Rocha Aguiar, Carolina Magri Ferraz, Alessandra Teixeira de Paula, Rosana Teixeira Lelis, Rosane Teixeira Lelis, Marilvia Dansa de Alencar, Rafaela Lorenzoni and Jackson Victor Araújo. 2016. Development of Nematophagous Fungi on Dead Adults of Aedes aegypti (Diptera: Culicidae) and Molt Inhibition Experimental. Int.J.Curr.Microbiol.App.Sci.5(2): 523531. doi: http://dx.doi.org/10.20546/ijcmas.2016.502.059 